\title{
A review on macrobenthic trophic relationships along subtropical sandy shores in southernmost Brazil
}

\author{
Raphael Mathias Pinotti, ${ }^{1,2,3}$, Diogo Marroni Minasi ${ }^{1}$, Leonir André Colling ${ }^{1}$ \& Carlos Emílio Bemvenuti ${ }^{I}$ \\ ${ }^{1}$ Laboratório de Ecologia de Invertebrados Bentônicos, Instituto de Oceanografia, Universidade Federal do \\ Rio Grande - FURG, Rio Grande, RS, Brazil. \\ ${ }^{2}$ Programa de Pós-Graduação em Oceanografia Biológica, Instituto de Oceanografia, Universidade Federal \\ do Rio Grande - FURG, Rio Grande, RS, Brazil. CNPq Postgraduate grant. \\ ${ }^{3}$ Corresponding author: Raphael Mathias Pinotti, e-mail: pinottirm@gmail.com
}

PINOTTI, R.M., MINASI, D.M., COLLING, L.A., BEMVENUTI, C.E. A review on macrobenthic trophic relationships along subtropical sandy shores in southernmost Brazil. Biota Neotropica. 14(3): e20140069. http://dx.doi.org/10.1590/1676-06032014006914

\begin{abstract}
Main trophic relationships that occur along the exposed sandy shores in southernmost Brazil $\left(\sim 33^{\circ} \mathrm{S}\right)$ are established taking into account several biological compartments operating at morphodynamically distinct environments. Beaches are predominantly of the intermediate type but some stretches of coastline are truly dissipative (Cassino Beach) or tending-to-reflective (Concheiros Beach), presenting thus diverse biological compartments and inhabitant macrobenthic assemblages. Dense concentrations of the surf-zone diatom Asterionellopsis glacialis are responsible - at least for the intermediate shorelines - for the most year-round primary production, sustaining several consumers up to tertiary level. Among them, bivalves Amarilladesma mactroides, Donax hanleyanus and the hippid crab Emerita brasiliensis can account for more than $95 \%$ of all the surf-zone secondary production, in addition to the elevated biomass of the suspension-feeder polychaete Spio gaucha and the scavenger isopod Excirolana armata. Crabs, whelks, carnivorous polychaetes, seabirds and surf-zone fishes may also be present and occupy superior trophic levels depending on the beach morphodynamics. Based on the high species richness, abundance and the role of macrobenthic fauna in transferring matter and energy to seabirds and the surf-zone fish assemblages, we address this important issue on the Southwestern Atlantic ecology. Conservation efforts should be implemented for the southernmost Brazilian sandy shores, at least for those non urbanized areas.
\end{abstract}

Keywords: exposed beach, intermediate states, primary production, secondary consumers, conservation.

PINOTTI, R.M., MINASI, D.M., COLLING, L.A., BEMVENUTI, C.E. Revisão sobre as relações tróficas macrozoobentônicas ao longo da costa arenosa subtropical do extremo sul do Brasil. Biota Neotropica. 14(3): e20140069. http://dx.doi.org/10.1590/1676-06032014006914

Resumo: As principais relações tróficas observadas ao longo da costa arenosa exposta do extremo sul do Brasil $\left(\sim 33^{\circ} \mathrm{S}\right)$ são estabelecidas levando-se em consideração os vários compartimentos biológicos que operam em ambientes morfodinamicamente distintos. Estas praias são predominantemente do tipo intermediário, embora alguns trechos sejam dissipativos (Praia do Cassino) ou apresentem tendências reflectivas (Praia dos Concheiros), possuindo compartimentos biológicos diversificados e associações macrobentônicas residentes. Densas concentrações da diatomácea Asterionellopsis glacialis são responsáveis - pelo menos para as praias intermediárias - por grande parte da produtividade primária anual, sustentando vários consumidores até o nível terciário. Entre estes, os bivalves Amarilladesma mactroides, Donax hanleyanus e o crustáceo Emerita brasiliensis são responsáveis por mais de 95\% de toda a produção secundária da zona de surfe, em adição à elevada biomassa do poliqueta suspensívoro Spio gaucha e do isópode necrófago Excirolana armata. Caranguejos, gastrópodes, poliquetas carnívoros, aves marinhas e peixes da zona de surfe também podem estar presentes, ocupando níveis tróficos superiores dependendo da morfodinâmica praial. Baseado na alta riqueza de espécies, na abundância e no papel da macrofauna bentônica em transferir matéria e energia para as aves marinhas e as assembléias de peixes da zona de surfe, esta importante questão ecológica do Atlântico Sudoeste foi investigada. Esforços de conservação devem ser implementados nas praias arenosas do extremo sul do Brasil, pelo menos naquelas áreas não urbanizadas.

Palavras-chave: praia exposta, estágios intermediários, produção primária, consumidores secundários, conservação. 


\section{Introduction}

Coastlines around the globe are dominated by sandy shores, dynamic environments largely controlled by physical factors like waves, tides, sand grain size and slope (McLachlan \& Brown 2006). Processes and interactions of such factors can result in a wide range of morphodynamic states - from reflective to dissipative - although most beaches are intermediate between these extremes (Short 1996): reflective beaches are coarsegrained, steep and narrow environments whereas dissipative beaches present finer sediments, flat slopes, large wave periods and extensive surf zones.

Species richness, total abundance and biomass of the macrobenthic fauna along sandy shores tend to increase from reflective to dissipative states (Defeo \& McLachlan 2005, 2011, McLachlan \& Dorvlo 2005). Both Swash Exclusion Hypothesis (SEH: McLachlan et al. 1993) and latter the Habitat Harshness Hypothesis (HHH: Defeo et al. 2001, 2003) have already predicted such variations in population dynamics and life history traits. The Habitat Favorability Hypothesis (HFH) further suggests that benign (i.e. dissipative) environments or sites undisturbed by human activities may significantly favor intraspecific interactions and density-dependent processes (Caddy \& Defeo 2003) being therefore considered more suitable to the inhabiting macrofauna (McLachlan et al. 1995).

Threats to sandy beach ecosystems are amplified by human over-exploitation of resources and population shifts towards the cost (Roberts \& Hawkins 1999), inducing a wide source of stressors ranging from local (e.g. trampling, sewer discharge) to global impacts (e.g. sea-level rise, global warming) acting at multiple spatial-temporal scales (Defeo et al. 2009). Such human-induced threats can significantly endanger the sandy beach macrobenthic fauna and subsequently affect their complex food webs (McLachlan et al. 1981, Lercari et al. 2010) given their critical role in transferring energy and regenerating nutrients (Soares et al. 1997, Cisneiros et al. 2011).

Food webs at sandy environments are mainly based on marine sources like wrack and carrion (Colombini \& Chelazzi 2003, Dugan et al. 2003), microphytobenthos (Delgado 1989) and surf-zone diatoms (Odebrecht et al. 2013) which support (i) an independent interstitial food web; (ii) a surf-zone microbial loop; and (iii) a macroscopic food web (McLachlan et al. 1981, Heymans \& McLachlan 1996). The knowledge about the food web structure and trophic relationships on sandy shores has growing with the implementation of stable isotopes (SI) techniques (Colombini et al. 2011) and recent studies have evidenced that the number of trophic pathways and food web complexity are strongly linked to morphodynamics, increasing significantly from reflective to dissipative environments (Lercari et al. 2010, Bergamino et al. 2011, 2013).

Early quali-quantitative studies on both intertidal and surf zones indicated that the sandy beaches from southernmost Brazil are among the richest and highly productive sandy environments (Gianuca 1997a) but secondary production data are still lacking to build trophic pathways similar to those reported nearby e.g. the Uruguayan coastline (Lercari et al. 2010). This comprehensive review includes both published and unpublished data aiming to evidence the major trophic relationships and empirically trace the flows of matter through the food web compartments along the southern Brazilian sandy shores, serving as background information for further SI research or management of stakeholders.

\section{Study area overview}

\section{Beach morphodynamics}

Subtropical exposed sandy shores in southernmost Brazil extend along $220 \mathrm{~km}$ of a continuous NE-SW coastline between Rio Grande ( $\left.32^{\circ} 10^{\prime} \mathrm{S}\right)$ and Chuí $\left(33^{\circ} 45^{\prime} \mathrm{S}\right)$ and present distinct morphodynamic patterns (Calliari et al. 1996, Pereira et al. 2010): (i) immediately south of $32^{\circ} \mathrm{S}$, Cassino Beach presents fine sandy substrates and dissipative characteristics; (ii) along $\sim 40 \mathrm{~km}$ of coastline - between $33^{\circ} 20^{\prime} \mathrm{S}$ and $33^{\circ} 35^{\prime} \mathrm{S}-$ Concheiros Beach presents bimodal substrates (shell fragments and medium/fine sands) and tending-to-reflective beach states; and (iii) the remaining coastline, presenting extensive beach widths $(40-120 \mathrm{~m})$, large swash zones $(10-50 \mathrm{~m})$, gentle slopes $(1 / 15-100)$, fine quartz sands $(\sim 3.0$ phi) and intermediate morphodynamic states with intermediate/moderate low mobility (Figure 1).

\section{Coastal occupation \& sandy shore threats}

The Brazilian southern state of Rio Grande de Sul (RS) has one of the least developed shores in the country and less than $10 \%$ of the state population $\left(\sim 1110^{6}\right.$ habitants $)$ living along $620 \mathrm{~km}$ of an almost continuous coastline: most of developed coastal cities are concentrated in its northern region while just a few balnearios-like-towns are found southwards separated by long and "wild" shore segments (Esteves et al. 2000). The southern urbanized beaches of Cassino, Hermenegildo and Barra do Chui are moderately used by local habitants and fishermen the year-round but heavily frequented by tourists between late austral spring and early autumn (December-April) (Figure 2).

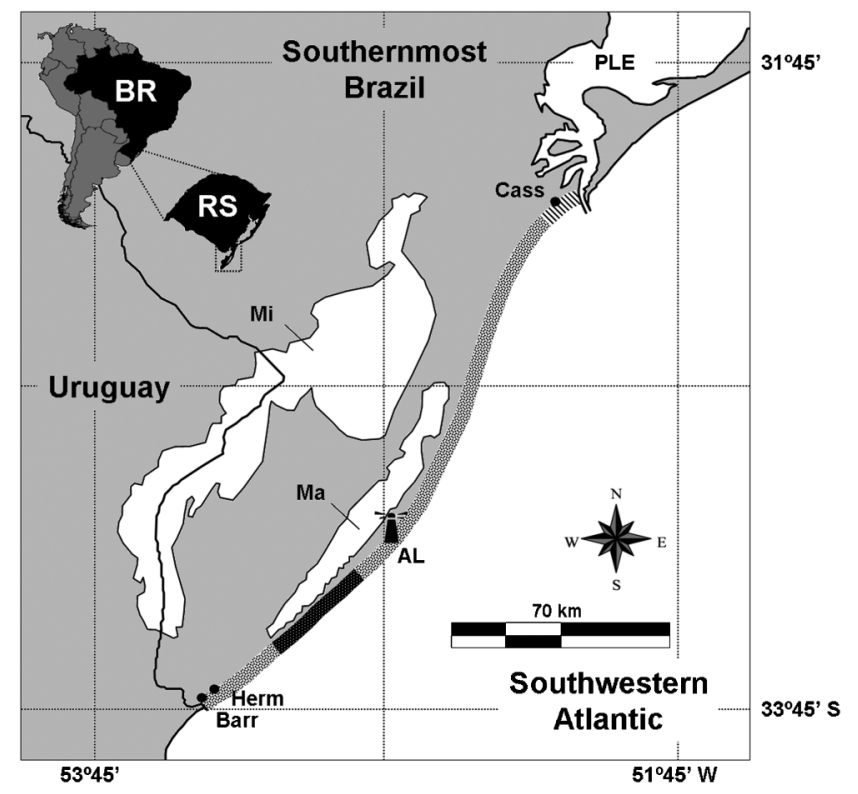

Figure 1. Subtropical sandy shores along the southernmost Brazil, presenting three sectors with distinct morphodynamic patterns: northern dissipative beaches (striped coastline); tending-to-reflective environments southwards the Albardão Lighthouse (AL), near the Concheiros Beach (dark coastline); and the remaining intermediate sandy shores (grainy coastline). The urbanized areas of Cassino Beach (Cass), Hermenegildo (Herm) and Barra do Chuí (Barr) are located. PLE: Patos Lagoon Estuary; Mi: Mirim Lagoon; Ma: Mangueira Lagoon. 

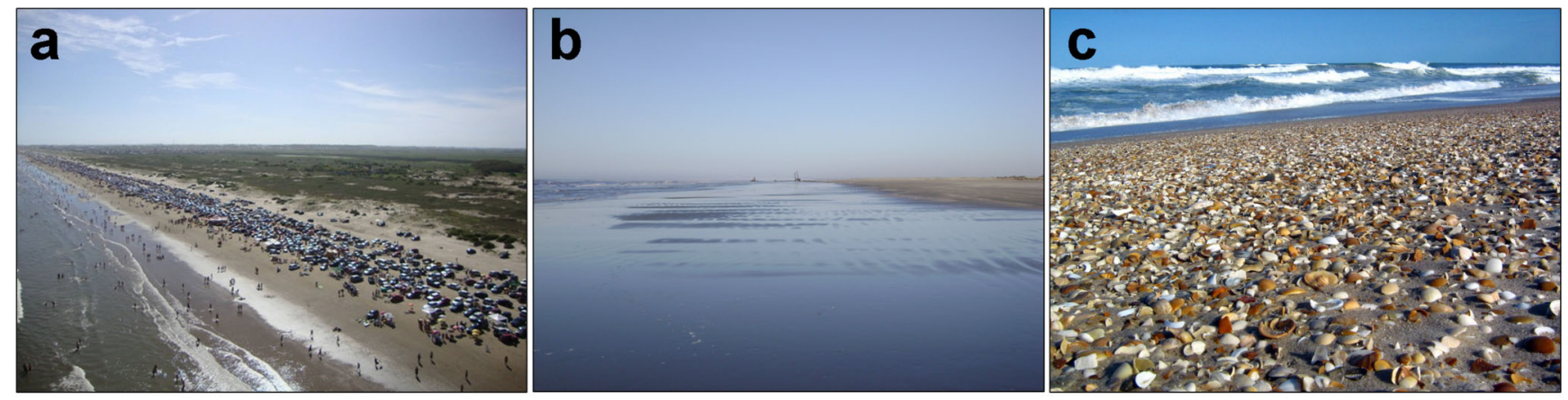

Figure 2. Contrasting degrees of morphodynamic characteristics and human occupation along the exposed sandy shores of southernmost Brazil: at the dissipative Cassino Beach, an intense traffic of vehicles and tourists occurs throughout the warmer months (a) in opposition to those "wild" southward segments of intermediate (b) and tending-to-reflective shores like the Concheiros Beach (c).

Despite the relatively low human occupation, several human-induced threats have exponentially endanger the macrobenthic fauna along this coastal area: artisanal overfishing, mainly over the yellow clam Amarilladesma (= Mesodesma $)$ mactroides and the ghost shrimp Sergio mirim; grooming and tourist trampling during the summer months; heavy traffic of vehicles including regular cars, ORVs and heavy trucks; inland freshwater discharge from agricultural and ranching activities; silviculture of exotic trees like Pinus sp.; intense harbor activities and dredge operations within the nearby Patos Lagoon estuary, increasing respectively the potential risk of biological invasions and mud depositions on Cassino Beach; and offshore oil-drilling operations to be implemented in the near future.

In addition, the sea-level rise due to global warming and the risk of macrobenthic strandings due to extreme weather events can potentially increase the list of local threats. Exotic macrobenthic species were not reported yet in the Southwestern Atlantic sandy shores but this may reflect a poor sampling coverage rather than lack of biological invasions (Orensanz et al. 2002, Defeo et al. 2009).

\section{Wave climate \& weather events}

The southern Brazilian beaches are exposed to moderate/ strong wave action ( $H b: 0.5-5.5 \mathrm{~m} ; T: 6-18 \mathrm{~s})$ under the influence of mixed-diurnal microtides $(<1 \mathrm{~m}$; annual average $\sim 0.5 \mathrm{~m}$ ) and thus classified as wave-dominated (Relative Tide Range < 3; sensu Masselink \& Short 1993).

Wave climate can be divided into three major groups (Tomazelli \& Villwock 1992, Figueiredo 2013): (i) swell waves of high amplitude and long period (mainly from S-SE); (ii) sea waves of short period (mainly from NE-E); and (iii) rare storm waves of high energy generally associated to storm surges. A biseasonal behavior is found superimposed on those overall morphodynamic patterns owing to the wave climate (Calliari \& Klein 1993): spring/summer accretion profiles (low swell) versus autumn/winter erosive profiles (storm waves).

Extreme weather events such as storm surges and waves associated or not to cyclogenesis (Parise et al. 2009) are responsible for significant beach erosion rates $\left(40-63 \mathrm{~m}^{3} \mathrm{~m}^{-1}\right)$ and dune field retractions (up to $\sim 5 \mathrm{~m}$ ), raising temporally the sea-level to the base of dunes $(>2.0 \mathrm{~m})$ especially when associated to spring tides (Calliari et al. 1998, Barletta \& Calliari 2003, Tabajara et al. 2004). The wind regime over the region (Krusche et al. 2003) presents predominance of NE winds during the spring/summer seasons (October-March) and strong southerly winds during the autumn/winter seasons (April-September). The rainfall regime is highly influenced by frontal systems and cyclogenesis (Rao \& Hada 1990, Diaz et al. 1998) and positively improved by ENSO El Niño phenomena (Grimm et al. 1998).

\section{Macrobenthic compartments}

\section{Zonation patterns}

The vertical distribution of the macrobenthic fauna along the southern Brazilian coast follows a typical zonation pattern (Borzone \& Gianuca 1990, Gianuca 1997a): foredunes, as the terrestrial/marine interface; supralittoral zone (or supratidal), dry-sand areas only inundated during extreme weather events (e.g. storm surge/waves); mesolittoral zone (or intertidal) including here the swash zone, frequently inundated by regular tides; and the infralittoral (or surf zone), divided into the inner surf zone (from the lower swash towards the $2 \mathrm{~m}$ isobath) and the outer surf zone (2-10 $\mathrm{m}$ isobaths).

Macrobenthic zonation may change according to the type of beach as the number of zones increase from reflective to dissipative states (Defeo et al. 1992, Jaramillo et al. 1993). Nevertheless, temporal fluctuations may difficult the recognition of such zonation schemes - especially along microtidal shores - given the unpredictable tidal movements and the seasonal distribution of species across the beach profile (Brazeiro \& Defeo 1996).

Along the intermediate sandy shores of southernmost Brazil (e.g. Cassino Beach), macrobenthic zonation was characterized as very dynamic through seasons despite the general 3-zone pattern (Neves et al. 2007): (i) supralittoral, occupied by burrows of the ghost crab Ocypode quadrata; (ii) upper mesolittoral, inhabited by the polychaete Thoracophelia furcifera (= Euzonus furciferus) and the isopod Excirolana armata; and (iii) a large lower zone including the lower mesolittoral and the inner surf zone, which was characterized by the intertidal migrants Amarilladesma mactroides and Donax hanleyanus in addition to several infralittoral species.

\section{Beach morphodynamics and macrobenthic assemblages}

The beach and surf zone of intermediate and dissipative coastlines may be characterized as a single semi-closed and selfsustaining ecosystem (sensu McLachlan 1980) in which the relative importance of each food web component may differ 
significantly between the extremes of a morphodynamic continuum (McLachlan \& Brown 2006): whereas beaches with little or no surf zone (i.e. reflectives) are nutrient sinking environments with low in situ primary production, beaches with extensive surf zones (i.e. intermediate/dissipatives) are highly productive environments driven by an intense phytoplanktonic primary production. As a consequence, components of nekton, benthos, plankton and microbial communities tend to increase diversity and biomass along these latter habitats (McLachlan \& Brown 2006).

The extensive southern Brazilian coast is predominantly of the intermediate type and presents high microalgae biomass mainly granted by accumulations of the surf-zone diatom Asterionellopsis glacialis (Castracane) Round throughout the year (Odebrecht et al. 2010, 2013). During high A. glacialis concentrations $\left(10^{7}\right.$ to ${ }^{9}$ cells $\left.\mathrm{L}^{-1}\right)$, high primary production rates (6.4 $\mathrm{mg} \mathrm{C} \mathrm{L}^{-1} \mathrm{~h}^{-1}$ ) and chlorophyll $a$ values (up to $4.7 \mathrm{mg}$ $\mathrm{L}^{-1}$ ) can be registered (Odebrecht et al. 1995, Rörig \& Garcia 2003). A decoupling mechanism between this surf-zone diatom and bacteria communities was also observed at Cassino Beach but, at least for this southern shore, the microbial loop is neither recycling nutrients nor serving as food source for other organisms in the food web (Abreu et al. 2003).

The primary producers within the surf zone constitute an important food source for intertidal species such as bivalves Amarilladesma mactroides and Donax hanleyanus (both filterfeeders), hippid crabs Emerita brasiliensis (suspension-feeder) and even other filter-feeding bivalves like Amiantis purpurata, Tivela spp. and Mactra isabelleana in the outer surf zone (Garcia $\&$ Gianuca 1997). Across the beach profile, accumulated annual production (ash-free dry weight; AFDW) of $A$. mactroides $(3,251$ $\left.\mathrm{g} \mathrm{m}^{-1}\right)$, E. brasiliensis $\left(499 \mathrm{~g} \mathrm{~m}^{-1}\right)$ and D. hanleyanus $\left(55 \mathrm{~g} \mathrm{~m}^{-1}\right)$ accounted for more than $95 \%$ of all the surf-zone secondary production (Gianuca 1983, 1997a), in addition to the biomass of the suspension-feeder polychaete Spio (= Scolelepis) gaucha $(35 \mathrm{~g}$ $\left.\mathrm{m}^{-2}\right)$ and the scavenger isopod Excirolana armata $\left(8 \mathrm{~g} \mathrm{~m}^{-2}\right)$ (Gianuca 1997a, Santos 1994). Ultimately, such species may transfer substantial portions of organic matter to secondary consumers, which are finally preyed by intermediate/top predators such as resident and migratory birds (Vooren \& Chiaradia 1990, Vooren 1997), supralittoral and infralittoral crabs (Wolcott 1978, Leber 1982) and also fish assemblages (Du Preez et al. 1990, Capítoli et al. 1994).

Besides the large predominance of intermediate beach states and the inhabiting macrobenthic assemblages, a singular stretch of dissipative coast is found northwards the Cassino Beach, near the Rio Grande western jetty (Calliari \& Klein 1993), presenting "almost endemic" macrobenthic species like Sergio mirim, the only ghost shrimp (Thalassinidea: Callianassidae) reported for these sandy shores (Pezzuto 1998). Burrows of $S$. mirim can be found in relative high density across the dissipative lower intertidal/shallow infralittoral zones - especially during low tides - providing shelter and resources to crabs Austinixa (= Pinnixa) patagoniensis and several other symbiotic species (Gianuca 1997a, Alves \& Pezzuto 1998). Exhibiting a (direct) deposit-feeding behavior, S. mirim storages organic matter within its burrow for later consumption on this enriched substrate (Coelho \& Rodrigues 2001). Local fishermen have conducted an increasing catch of ghost shrimps as bait especially during the summer and thus should be managed to avoid overfishing (Pezzuto 1998). Other macrobenthic species inhabiting this dissipative shoreline have already experiencing declines in terms of density and biomass due to human-induced threats, given the proximity to the Cassino urbanized area (Queiroz 2008, Viana 2008, Girão 2009).

Lowest diversity, density and biomass of macrobenthic fauna are associated to that intermediate-to-reflective portion of the southern Brazilian coast - the Concheiros Beach, near the Balneário Hermenegildo - a pattern also found southwards for intermediate and truly reflective beaches in the Uruguayan coast e.g. Arachania and Manantiales (Defeo et al. 1992, Lercari et al. 2010). A snapshot survey conducted at Concheiros Beach reported that macrobenthic zonation was not clear and that macrobenthic richness (five species only) and biomass were both low when compared to the surrounding shores, given the high concentration of shell debris within the substrate: bivalve Donax hanleyanus (up to $43 \mathrm{~g} \mathrm{~m}^{-2}$ ), hippid crab Emerita brasiliensis $\left(11 \mathrm{~g} \mathrm{~m}^{-2}\right)$, carnivorous polychaete Hemipodia californiensis $(=$ Hemipodus olivieri $)\left(0.2 \mathrm{~g} \mathrm{~m}^{-2}\right)$ and isopods Excirolana braziliensis $\left(0.5 \mathrm{~g} \mathrm{~m}^{-2}\right)$ and E. armata $\left(<0.1 \mathrm{~g} \mathrm{~m}^{-2}\right)$ (Barros et al. 1994). Recent seasonal and interannual surveys have significantly increased this short list of species: more than 21 macrobenthic taxa were so far identified for Concheiros Beach including polychaetes, flatworms, molluscs, nemerteans and crustaceans across the swash zone (Minasi 2013) whereas 28-75 burrows of ghost crabs Ocypode quadrata (1-4 mm to 13$16 \mathrm{~mm}$ ) were seasonally registered within the upper mesolittoral/supralittoral zones (Brauer 2013).

Comparing the ecosystem structure and trophic networks of two sandy beaches with contrasting morphodynamics, significant differences were reported concerning the number of biological compartments operating at dissipative (20) and reflective beaches (9), with the former presenting a higher number of top predators and superior trophic levels (Lercari et al. 2010). In southernmost Brazil such dissimilarities between intermediate and reflective sandy environments become evident, based on qualitative records, stomach content analyzes, field samplings and laboratory experiments (Table 1). Higher species richness at intermediate shores coincided with distinct composition and number of biological compartments when compared to reflective shores; nevertheless, such difference may be biased by the fewer studies conducted along these latter environments.

\section{Across-shore trophic relationships}

Based on this comprehensive compilation of data (Table 1), major trophic relationships are highlighted and across-shore described taking into account the biological compartments of producers, macrobenthic fauna, seabirds and surf-zone fishes present at the intermediate shores in southernmost Brazil (Figure 3), as follows:

\section{Supralittoral zone}

By the action of strong SW winds, due to storm events or after the passage of frontal systems, vegetal detritus and high phytoplankton concentrations are both carried to the uppershore forming extensive deposits of organic matter along the beach. Dense accumulations of the surf-zone diatom Asterionellopsis glacialis generally form dark-brown patches at the meso/supralittoral (Odebrecht et al. 2013), representing an important food source for terrestrial coleopterans (Bledius spp.) and the talitrid amphipod Atlantorchestoidea brasiliensis, a scavenger/detritivore species (Gianuca 1983). The abundant presence of the rove beetle Bledius bonariensis $\left(2,350\right.$ ind. $\left.\mathrm{m}^{-2}\right)$ 
Table 1. Species richness and biological compartments from supralittoral to the inner surf zone at intermediate (INT) and reflective (REF) sandy shores in southernmost Brazil. Taxonomic classification is presented when available. $p$ : presence; —: absence; ?: unknown report / poor sampling. Anom: Anomura; Anopl: Anopla; Bival: Bivalvia; Brachy: Brachyura; Carab: Carabinidae; Gamma: Gammaridea; Gastr: Gastropoda; Isop: Isopoda; Polyc: Polychaeta; Staph: Staphynelidae; Talitr: Talitridae.

\begin{tabular}{llll}
\hline Marine and "terrestrial" species & Taxonomy & INT & REF \\
& & ( a ) & ( b ) \\
\hline
\end{tabular}

\section{CRUSTACEA}

Arenaeus cribrarius (Lamarck, 1818)

Atlantorchestoidea brasiliensis (Dana, 1853)

Bathyporeiapus bisetosus Escofet, 1970

Chiriscus giambiagiae (Torti \& Bastida, 1972)

Emerita brasiliensis Schmitt, 1935

Excirolana armata (Dana, 1853)

Excirolana braziliensis Richardson, 1912

Macrochiridothea lilianae Moreira, 1972

Ocypode quadrata (Fabricius, 1787)

Phoxocephalopsidae amphipods

Platyischnopidae amphipods

\section{MOLLUSCA}

Amarilladesma mactroides (Reeve, 1854)

Buccinanops duartei Klappenbach, 1961

Donax gemmula Morrison, 1971

Donax hanleyanus Philippi, 1847

Olivancillaria auricularia (Lamarck, 1811)

Olivancillaria orbignyi (Marrat, 1868)

ANNELIDA

Hemipodia californiensis (Hartman, 1938)

Nephtys simoni Perkins, 1980

Sigalion cirrifer Orensanz \& Gianuca, 1974

Spio gaucha Orensanz \& Gianuca, 1974

Thoracophelia furcifera Ehlers, 1897

INSECTA

Bledius bonariensis Bernhauer, 1912

Bledius fernandezi Bernhauer, 1939

Bledius microcephalus Fauvel, 1901

Cicindela conspersa Dejean, 1825

Cicindela patagonica Horn, 1895

Tetragonoderus variegatus Dejean, 1825

NEMERTEA

\section{SEABIRDS}

FISHES

ZOOPLANKTON

PHYTOPLANKTON

Brachy
Talitr
Gamma
Isop
Anom
Isop
Isop
Isop
Brachy
Gamma
Gamma

$\begin{array}{ll}p & ? \\ p & ? \\ p & p \\ p & p \\ p & p \\ p & p \\ p & ? \\ p & - \\ p & p \\ p & p \\ p & p\end{array}$

Bival

Gastr

Bival

Bival

Gastr

Gastr

Polyc

Polyc

Polyc

Polyc

Polyc

$\begin{array}{ll}p & p \\ p & ? \\ p & - \\ p & p \\ p & ? \\ p & ?\end{array}$

Based on references for southern Brazilian (a) intermediate beaches: Gianuca (1983, 1997), Girão (2009), Neves et al. (2007, 2008, 2012), Queiroz (2008), Silva et al. (2008), Viana (2008); (b) reflective beaches: Barros et al. (1994), Brauer (2013), Minasi (2013); (c) seabirds: Vooren \& Chiaradia (1990), Vooren (1997); (d) fishes: Capítoli et al. (1994), Monteiro-Neto et al. (2003), Lima \& Vieira (2009), Rodrigues \& Vieira (2010); (e) zooplankton: Bersano (1994); (f) phytoplankton: Odebrecht et al. (1995, 2010, 2013).

and the tiger beetle Cicindela conspersa may attract coleopteran predators like the ground beetle Tetragonoderus variegatus, being all ultimately preyed by resident birds like the collared plover Charadrius collaris and the pipit Anthus correndera (Garcia \& Gianuca 1997).

The supralittoral zone of exposed sandy beaches are typically inhabited by several species of insects, amphipods, isopods and crabs of the genus Ocypode, this latter worldwide distributed in tropical and subtropical sandy shores (McLachlan \& Brown 2006). The ghost crab Ocypode quadrata presents a generalist feeding behavior and actively moves from the supralittoral down to the upper swash zone during low tides to prey on live intertidal migrants (e.g. Donax and Emerita species), flesh of large dead animals (e.g. fishes) or even deposited phytoplankton from the substrate (Wolcott 1978, Leber 1982, Robertson \& Pfeiffer 1982, Trott 1999).

Ocypode quadrata excavates burrows across the mesolittoral (juveniles) and supralittoral zones (adults) of southern Brazil (Alberto \& Fontoura 1999, Girão 2009) and scavenges macrobenthic strandings after storm surge events, when 


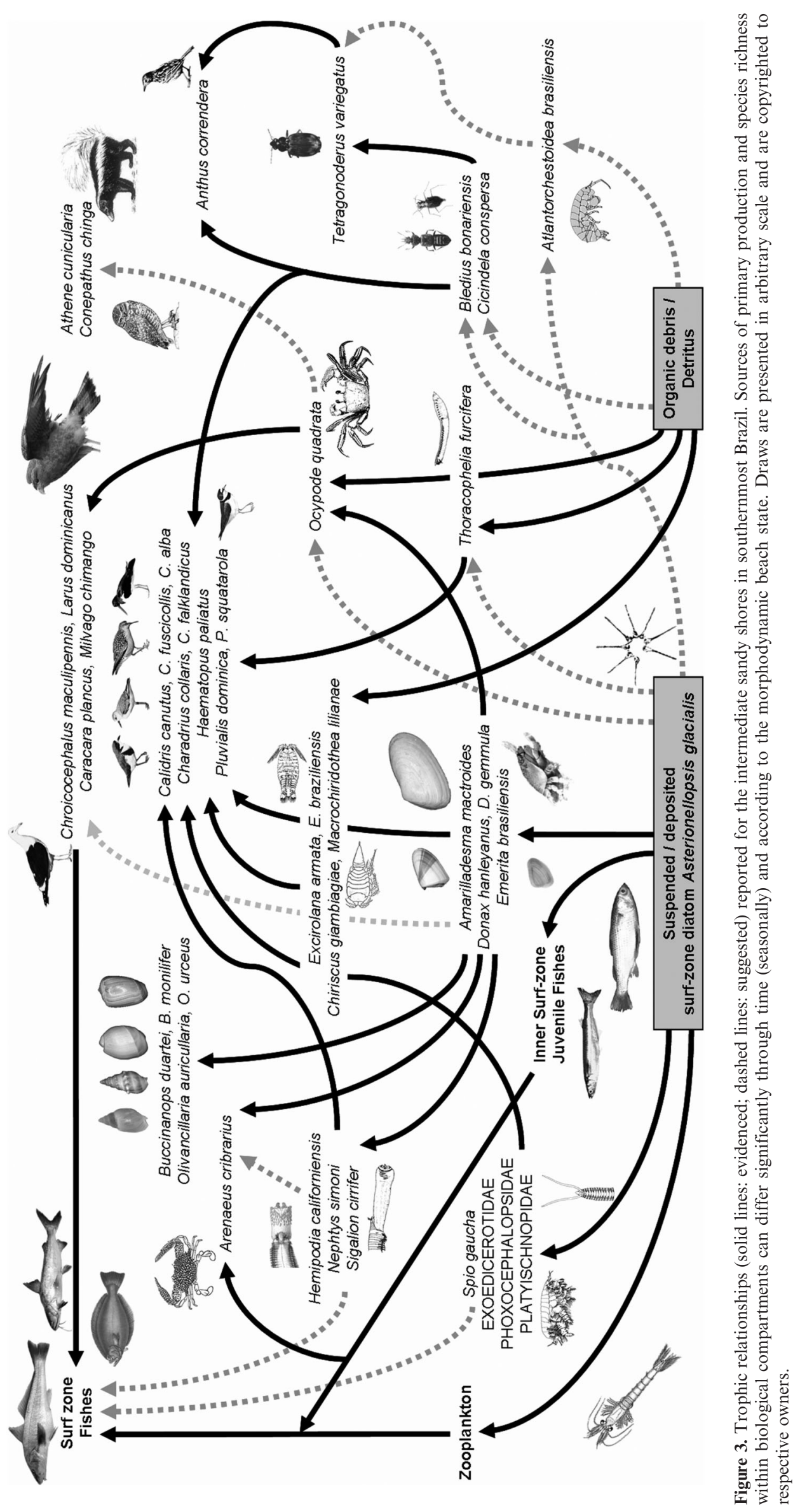


Amarilladesma mactroides and Donax hanleyanus empty shells and Emerita brasiliensis debris are registered around large burrows of the ghost crab (pers. obs.). Macrobenthic strandings result from the passive transport of several intertidal/infralittoral species to the upper parts of the beach due to strong hydrodynamics and SW winds, determining massive mortality due to their trapping in the dry sand and dying by desiccation, starvation, predation or human-induced factors (Neves et al. 2008, Pinheiro 2013, Pinotti \& Bemvenuti in prep.).

Nocturnal activities of Ocypode quadrata are commonly reported for populations inhabiting the southern coast of Rio Grande do Sul state, even under favorable daytime temperatures e.g. $25{ }^{\circ} \mathrm{C}$ (Alberto \& Fontoura 1999). Along Moçambique Beach (Florianópolis, SC, Brazil) such night-time behavior was considered an important strategy to keep away from diurnal predators like seagulls and falconid species (Blankensteyn 2006). Avoid daylight exposure may decrease predation rates over $O$. quadrata if taken into account the high diversity and abundance of predatory birds foraging alone or in flocks during the day along the southern Brazilian shores (Vooren \& Chiaradia 1990). On the other hand, such behavior does not prevent the nocturnal predation of other animals like the burrowing owl Athene cunicularia and the skunk Conepathus chinga, both inland predators alternatively feeding on this crab (Gianuca 1997b).

Other inland top predators found over the entire beach all year round are seagulls (Larus dominicanus and Chroicocephalus maculipennis) and hawks (Milvago chimango and Caracara plancus) which also feed on stranded debris, wind-blown insects and discards of coastal fishery (Vooren 1997).

\section{Mesolittoral zone}

The shore exposure to strong winds from S-SW quadrants (mainly through the cold seasons) determine an abundant availability of food sources (suspended/deposited) to the inhabiting intertidal macrofauna, mostly granted by high concentrations of the surf-zone diatom Asterionellopsis glacialis (Garcia \& Gianuca 1997).

The infaunal polychaete Thoracophelia furcifera is commonly registered along the upper/mid-intertidal zones from sandy beaches of southern Brazil and northern Uruguay, from the surface up to $20 \mathrm{~cm}$ deep (Defeo et al. 1992, Brazeiro \& Defeo 1996, Neves et al. 2007). This small Opheliidae ( $<2 \mathrm{~cm}$ long, $\sim 3$ mm wide), usually classified as a deposit-feeder (Fauchald \& Jumars 1979), may utilize that organic matter derived from $A$. glacialis deposits within the substrate whilst exploiting bacteria and other microbes as carbon source (Kemp 1986). Under severe insolation and consequent drying of the sand surface, elevated concentrations of $T$. furcifera are found deeper in the substrate; conversely, when the water table is high and the sand is wet, higher polychaete densities are found near the surface (Viana 2008), occasion in which T. furcifera and abundant intertidal migrants may constitute significant food sources for the northern migrant sandpipers Calidris spp. (Vooren \& Chiaradia 1990, Vooren 1997).

The scavenger isopod Excirolana armata is generally characterized as a primary consumer exposed to high predation pressure (Lercari et al. 2010). Inhabiting the intermediate to lower intertidal, E. armata swims and burrows faster than other Cirolanid found in upper levels - E. braziliensis - but both are capable of actively pursuit prey and search for carrion under a wide range of swash currents (Yannicelli et al. 2002). Several macrobenthic species and even large dead organisms (e.g. fishes, seabirds) are voraciously consumed by hundreds of Excirolana isopods which literally swarm the carcasses while feeding (pers. obs.), thus accelerating the recycling of organic matter (McLachlan \& Brown 2006). During the summer months, dense flocks of sandpipers Calidris canutus, $C$. fuscicollis and $C$. alba can be found foraging on E. armata isopods within the upper swash zone, on slightly submerged substrates or even on dry sand (Vooren 1997).

Probing the substrate with their fine bills and localizing the prey through touch and taste (and even visually), Calidris sandpipers also adopt this forage strategy to efficiently prey on Amarilladesma mactroides (recruits to juveniles), Donax hanleyanus and Emerita brasiliensis (Vooren \& Chiaradia 1990, Vooren 1997). Such intertidal migrants may achieve high densities across the beach profile especially during recruitment peaks, between late spring and early autumn (Neves et al. 2007). The above species and E. armata are also significantly preyed in a solitary manner by charadriid plovers Charadrius falklandicus (southern migrant), C. collaris (resident species), Pluvialis dominica and P. squatarola (both northern migrants), which search their prey exclusively by visual means at the upper swash zone and to a lesser extent on slightly submerged sands (Vooren 1997). As a result, intertidal migrants can account for $90 \%$ of the stomach content of sandpipers and plovers by the end of summer (Garcia \& Gianuca 1997).

Omnivorous-detritivorous amphipods like Bathyporeiapus bisetosus and B. ruffoi (Exoedicerotidae), Phoxocephalopsis zimmeri and Puelche orensanzi (Phoxocephalopsidae) and Platyischnopidae amphipods may utilize part of primary (or even secondary) production for nourishment along the swash zone, where suspended/deposited diatoms and detritus are important food sources (Escofet 1973, Lercari et al 2010). Linking the primary production to higher trophic levels, such amphipod species may be characterized as potential food items in the diet of those migrant/resident sandpipers and plovers, given the macrobenthic distribution across the beach profile and the shorebird feeding strategies (Vooren 1997, Neves et al. 2007).

Endemic in southern Brazil, Uruguay and northern Argentina exposed sandy beaches, the polychaete Spio gaucha is commonly found across the entire mesolittoral zone, reaching elevated mean annual biomass (up to $31 \mathrm{~g} \mathrm{AFDW} \mathrm{m}^{-1}$ ) and production (up to $113 \mathrm{~g} \mathrm{AFDW} \mathrm{m}^{-1}$ year $^{-1}$ ) due to extremely high densities (up to 100,000 ind. $\mathrm{m}^{-2}$ ), especially during spring and early summer (Santos 1991, 1994). Such infaunal species constructs a weak cohesive tube within the first $20 \mathrm{~cm}$ of sand, exhibiting a suspension-feeding behavior near the substrate surface (Santos 1991). Indeed, Scolelepis sp. feed predominantly on suspended particles within the intertidal zone but may opportunistically change to a deposit-feeding strategy under still environmental conditions (Pardo \& Amaral 2004). Regardless the feeding behavior, $S$. gaucha may utilize that abundant offer of suspended and/or deposited diatoms (mainly Asterionellopsis glacialis) for nourishment, linking such primary production to higher trophic levels and thus playing an important role in sandy beach ecosystem functioning (Speybroeck et al. 2007).

Sandpipers and plovers are shorebirds with short bills well adapted to prey on small macrobenthic fauna living shallowly nearby the substrate surface (Santos 1991, Vooren 1997). On the other hand, the shape and size of the bill and the specialized searching behavior of the American oystercatcher Haematopus 
palliatus allow the species to feed preferentially on large yellow clams Amarilladesma mactroides (Vooren \& Chiaradia 1990). This intertidal migrant exhibits a shallow behavior within the first $\mathrm{cm}$ layers during early stages of development, but reaches $15-40 \mathrm{~cm}$ deep in the sediment when adult $(>50 \mathrm{~mm})$ using the strong foot to dig and anchor (Narchi 1981, Penchaszadeh 2004). Buried across the swash zone at depths around $5 \mathrm{~cm}$, large clams are available neither to other birds (e.g. sandpipers, plovers) nor to marine predators (e.g. fish assemblages) except when emerging to migrate with tides; then, they are also preyed by the resident seagulls Larus dominicanus (Vooren 1997). Dense beds of $A$. mactroides $\left(2-610^{3}\right.$ ind. $\mathrm{m}^{-2}$ ) are broadly found across the swash zone especially between late spring and early autumn (Neves et al. 2007) when they are heavily preyed, reinforcing that important link of trophic transference between macrobenthic species and bird compartments (Garcia \& Gianuca 1997).

\section{Infralittoral (inner and outer surf zones)}

Under the influence of regular wave action and strong currents, the inner surf zone of southernmost Brazil is characterized as a turbulent environment, in which the frequent winter storms further increase such stressful hydrodynamics (Gianuca 1997). During extremely low tides, sandpipers and plovers may alternatively feed on Donax gemmula (highly abundant), isopods Chiriscus giambiagiae and Macrochiridothea lilianae, and also on polychaetes Sigalion cirrifer, Hemipodia californiensis and Nephtys simoni, given their frequency and abundance within the interface lower swash zone/inner surf zone (Gianuca 1997). The infaunal polychaetes do not reach those high densities of the intertidal Spio gaucha but attain a much larger body size and consequently higher biomass per individual (pers. obs.), preying actively on the meiofauna (e.g. nemerteans, ostracods, harpacticoid copepods) or ingesting post-settled recruits of the macrofauna (e.g. bivalves, polychaetes, crustaceans) specially during recruitment peaks (Neves et al. 2007).

Several marine decapods, whelks and juvenile fishes from the surf zone are generally reported moving into the lower mesolittoral during high tides, promoting significant predation excursions (Garcia \& Gianuca 1997). The speckled swimming crab Arenaeus cribrarius is a voracious predator, being frequently registered across the swash zone searching for living prey (e.g. bivalves, gastropods and other invertebrates) or meat in decomposition. Both juveniles and adults of A. cribrarius display a generalist carnivorous behavior in which prey are selected according to the capture capacity and swimming ability of different size classes (Warner 1977). Intertidal migrant species like Amarilladesma mactroides (recruits to juveniles), Donax hanleyanus and Emerita brasiliensis are recognized as important food sources for $A$. cribrarius given their abundance near the substrate surface as shallow filter-/suspension-feeders, a predation-prey relationship also reported elsewhere (Leber 1982). Furthermore, we can not disregard the inner surf zone polychaetes Sigalion cirrifer, Hemipodia californiensis and Nephtys simoni as recurrent food sources in the swimming crab diet given the high burrowing capacity of portunid crabs (Warner 1977).

Surf zone whelks like Buccinanops duartei and Olivancillaria auricularia (0-5 m depth), B. monilifer and O. urceus (5-8 m) are either predators or scavengers frequently registered in predatory excursions across the swash zone/inner surf zone (Borzone \& Gianuca 1990, Garcia \& Gianuca 1997), expanding their large foot muscle to burrow the sand (anchoring) or efficiently ride the swash waves (surfing) up and down the beach (Penchaszadeh 2004). Employing an accurate chemical perception to detect debris of dead animals or living prey, Buccinanops species take advantage of their strong foot to capture food sources, including young/small Donax hanleyanus and Emerita brasiliensis (Rios 2009). Similar displacement and hunt strategies are also exhibited by Olivancillaria species when preying over small clams, especially $D$. hanleyanus and juveniles of Amarilladesma mactroides (Penchaszadeh 2004).

The ichthyofauna is usually dominated by benthic feeders moving into shallow waters to feed on benthos and alternatively on zooplankton, being therefore characterized as higher predators (Lasiak \& McLachlan 1987; Du Preez et al. 1990). The zooplankton community in southernmost Brazil is broadly dominated by mysids (highly abundant) and copepods (more diverse) in addition to several meroplanktonic larvae, accounting for a high biomass within the surf zone (up to $810^{3} \mathrm{mg} \mathrm{C} \mathrm{m}^{-3}$; Bersano 1994). Such elevated zooplankton biomass is likely to exert a significant grazing pressure over the phytoplankton community.

The shallow depth in the inner surf zone generally limits the access of large fishes whilst may provide an important nursery area for juveniles (Lasiak 1981). Along the southern Brazilian coast, Monteiro-Neto et al. (2003) reported 43 fish species across this shallow zone $(0-1.2 \mathrm{~m})$, with juveniles ranging between $15-150 \mathrm{~mm}$ of total length. A more recent study within this zone also revealed a significant differentiation between resident and seasonal species (Lima \& Vieira 2009). Among some of those surf zone inhabitants, juveniles of pampo Trachinotus marginatus do not feed on macrobenthic fauna whilst the silverside Odonthestes argentinensis alters the main food source from diatoms to zooplankton during its development (Bemvenuti 1990). The mullets Mugil platanus and $M$. gaimardianus ingest zooplankton and deposited material over the substrate while offshore, including the diatom Asterionellopsis glacialis (Vieira 1991, Garcia \& Gianuca 1997).

The vertical distribution of the macrobenthic fauna across the southern Brazilian surf zone is a function of depth, where 126 species form three distinct assemblages (Borzone \& Gianuca 1990): a shallow assemblage (2-5 m of depth), characterized by whelks Olivancillaria auricularia and Buccinanops duartei, bivalves Corbula sp. and Donax gemmula, polychaetes Sigalion cirrifer and Diopatra viridis, the isopod Macrochiridothea lilianae and the sand dollar Mellita quinquiesperforata; an intermediate assemblage $(5-8 \mathrm{~m})$ with shared composition and thus higher diversity; and a deeper assemblage $(8-10 \mathrm{~m})$ dominated by abundant polychaetes Kinbergonuphis difficilis and Paraprionospio pinnata, bivalves Mactra isabelleana and Tellina spp., the gastropod Duplicaria gemmulata and the polychaetes Pherusa capitata, Glycinde multidens and Glycera americana. Several other species like the cumacean Diastylis sympterygiae, isopods Synidotea marplatensis and Ancinus gaucho, molluscs Abra lioica and Anachis isabellei and the polychaete Parandalia sp. present a wider distribution and also higher density throughout the outer surf zone (Borzone \& Gianuca 1990).

This high macrobenthic richness/density and the high abundance of juvenile fishes in deeper waters of the outer surf zone (2-10 $\mathrm{m}$ depth) distinguishes this zone as an important feeding ground to fishes, comprising secondary or even higher consumers: adults of T. marginatus; kingcroakers Menticirrhus americanus and M. littoralis; banded croaker Paralonchurus 
brasiliensis; flatfishes Oncopterus darwini and Paralichthys orbignyanus; whitemouth croaker Micropogonias furnieri; and catfishes Genidens barba and G. planifrons (Monteiro-Neto \& Cunha 1990; Capítoli et al. 1994, Rodrigues \& Vieira 2010). Large individuals of Pogonias cromis (black drum) may feed abundantly on the filter-feeding bivalves $A$. purpurata, Tivela spp. and M. isabelleana (Garcia \& Gianuca 1997).

From the inner shelf to the upper slope, even more diverse and abundant macrobenthic assemblages are found in the southwestern Atlantic (Absalão 1990, 1991; Capítoli \& Bemvenuti 2004, 2006) supporting demersal and benthic teleost fish assemblages, many of them commercially valuable (Haimovici 1997); nevertheless, such trophic relationships within/between deeper marine zones are beyond the scope of the present revision.

\section{Summary \& conclusions}

The southernmost Brazilian sandy shore is characterized as primarily intermediate, despite those dissipative (Cassino Beach) and tending-to-reflective (Concheiros Beach) stretches of coast (Calliari et al. 1996). Along this shoreline, the surf-zone diatom Asterionellopsis glacialis is the most important primary producer, sustaining intermediate (secondary to tertiary) macrobenthic consumers like filter-feeding bivalves, hippid crabs and scavenger isopods, forming short trophic chains (Heymans \& McLachlan 1996, Lercari et al. 2010, Colombini et al. 2011).

During short-term high tides, the elevated abundance and consequent high biomass of intertidal species along the southern Brazilian shores may attract several top-predators like swimming crabs, whelks and fishes (upshore) whilst the predation threats are mainly exerted by ghost crabs and seabirds (downshore) at low tides (Gianuca 1983). Only ghost crabs, some carnivorous gastropods and polychaetes (mainly Hemipodia californiensis) may conversely integrate the superior trophic levels on Concheiros Beach, given the virtual absence of bird and fish assemblages along reflective shorelines due to limited swash/surf zone widths (Lercari et al. 2010). Dissipative beaches have higher number of species occupying higher trophic levels whilst reflective environments exhibit higher levels of connectance and omnivory, increasing the trophic network robustness to secondary extinctions (due to primary species loss e.g. by biological invasions and/or habitat loss) and therefore enhancing the ecosystem stability (Bergamino et al. 2013).

Given its role as nursery and growth area to juvenile/adult fish assemblages and as strategic feeding area for resident/ migrant seabirds, conservation efforts should be heavily implemented for the southernmost Brazilian intermediate shores, at least for those non urbanized segments. Such strategies could be focused on preserve the dune fields and their natural vegetation, prohibiting the traffic of vehicles along the beach, limiting the access of tourists and regulate the invertebrate fisheries over the yellow clam Amarilladesma mactroides and the ghost shrimp Sergio mirim.

\section{Acknowledgments}

We would like to thank the anonymous reviewers for their critics and improvements on the original manuscript. This research was financially supported by the National Council for Scientific and Technological Development - CNPq (141132/ 2010-8).

\section{References}

ABREU, P.C., RÖRIG, L.R., GARCIA, V.M., ODEBRECHT, C. \& BIDDANDA, B. 2003. Decoupling between bacteria and the surfzone diatom Asterionellopsis glacialis at Cassino Beach, Brazil. Aquat. Microb. Ecol. 32:219-228, http://dx.doi.org/10.3354/ame032219

ABSALÃO, R.S. 1990. Ophiuroid assemblages off the Lagoa dos Patos outlet, Southern Brazil. Ophelia. 31(2):133-143, http://dx.doi.org/ 10.1080/00785326.1990.10430857

ABSALÃO, R.S. 1991. Environmental discrimination among softbottom mollusk associations off Lagoa dos Patos, south Brazil. Est. Coast. Shelf Sci. 32:71-85, http://dx.doi.org/10.1016/02727714(91)90029-B

ALBERTO, R.M.F. \& FONTOURA, N.F. 1999. Distribuição e estrutura etária de Ocypode quadrata (Fabricius, 1787) (Crustacea, Decapoda, Ocypodidae) em uma praia arenosa do litoral sul do Brasil. Rev. Bras. Biol. 59(1):95-108, http://dx.doi.org/10.1590/ S0034-71081999000100013

ALVES, E.S. \& PEZZUTO, P.R. 1998. Population dynamics of Pinnixa patagoniensis Rathbun, 1918 (Brachyura, Pinnotheridae) a symbiotic crab of Sergio mirim (Thalassinidea: Callianassidae) in Cassino Beach, southern Brazil. Mar. Ecol. 19(1):37-51, http:// dx.doi.org/10.1111/j.1439-0485.1998.tb00452.x

BARLETTA, R.C. \& CALLIARI, L.J. 2003. An assessment of the atmospheric and wave aspects determining beach morphodynamic characteristics along the central coast of RS state, Southern Brazil. J. Coast. Res. 35(SI):300-308.

BARROS, F.C.R., CALLIARI, L.J. \& GIANUCA, N.M. 1994. Estudo preliminar da macrofauna bentônica da Praia dos Concheiros, RS. Not. Téc. UFRGS. 7:33-37.

BEMVENUTI, M.A. 1990. Hábitos alimentares de peixes-rei (Atherinidae) na região estuarina da Lagoa dos Patos, RS, Brasil. Atlântica. 12(1):79-102.

BERGAMINO, L., LERCARI, D. \& DEFEO, O. 2011. Food web structure of sandy beaches: temporal and spatial variation using stable isotope analysis. Est. Coast. Shelf Sci. 91(4):536-543, http:// dx.doi.org/10.1016/j.ecss.2010.12.007

BERGAMINO, L., GÓMEZ, J., BARBOZA, F.R. \& LERCARI, D. 2013. Major food web properties of two sandy beaches with contrasting morphodynamics, and effects on the stability. Aquat. Ecol. 47(3):253-261, http://dx.doi.org/10.1007/s10452-013-9440-5

BERSANO, J.G. 1994. Zooplâncton da zona de arrebentação, de praias arenosas situadas ao sul de Rio Grande, RS. Primavera de 1990 / Verão de 1991. MSc. Dissertation in Biological Oceanography, Federal University of Rio Grande - FURG, Rio Grande, Brazil.

BLANKENSTEYN, A. 2006. O uso do caranguejo maria-farinha Ocypode quadrata (Fabricius) (Crustacea, Ocypodidae) como indicador de impactos antropogênicos em praias arenosas da Ilha de Santa Catarina, Santa Catarina, Brasil. Rev. Bras. Zool. 23(3):870-876, http://dx.doi.org/10.1590/S0101-81752006000300034

BORZONE, C.A. \& GIANUCA, N.M. 1990. A zonação infralitoral em praias arenosas expostas. Pub. ACIESP. 71(3):280-287.

BRAUER, B. 2013. Distribuição e abundância do caranguejo Ocypode quadrata nas praias arenosas do extremo sul do Brasil. Monograph in Oceanography, Federal University of Rio Grande - FURG, Rio Grande, Brazil.

BRAZEIRO, A. \& DEFEO, O. 1996. Macroinfauna zonation in microtidal sandy beaches: is it possible to identify patterns in such variable environments? Est. Coast. Shelf Sci. 42:523-536, http:// dx.doi.org/10.1006/ecss.1996.0033

CADDY, J.F. \& DEFEO, O. 2003. Enhancing or restoring the productivity of natural populations of shellfish and other marine invertebrate resources. FAO Fish. Tech. Paper 448. FAO, Rome.

CALLIARI, L.J. \& KLEIN, A.H.F. 1993. Características morfodinâmicas e sedimentológicas das praias oceânicas entre Rio Grande e Chuí, RS. Pesq. Geoc. 20(1): 48-56. 
CALLIARI, L.J., KLEIN, A.H.F. \& BARROS, F.C.R. 1996. Beach differentiation along the Rio Grande do Sul coastline (Southern Brazil). Rev. Chil. Hist. Nat. 69:485-493.

CALLIARI, L.J., TOZZI, H.A.M. \& KLEIN, A.H.F. 1998. Beach morphology and coastline erosion associated with storm surge in Southern Brazil - Rio Grande to Chuí, RS. An. Acad. Bras. Cienc. 70(2):231-247.

CAPÍTOLI, R.R. \& BEMVENUTI, C.E. 2004. Distribuição batimétrica e variações de diversidade dos macroinvertebrados bentônicos da plataforma continental e talude superior no extremo sul do Brasil. Atlântica. 26(1):27-43.

CAPÍTOLI, R.R. \& BEMVENUTI, C.E. 2006. Associações de macroinvertebrados bentônicos de fundos inconsolidados da plataforma continental e talude superior no extremo sul do Brasil. Atlântica. 28(1):47-59.

CAPÍtOLI, R.R., BAGER, A. \& RUFFINO, M.L. 1994. Contribuição ao conhecimento das relações tróficas bentônicodemersais nos fundos de pesca do camarão Artemesia longinaris Bate, na região da barra da Lagoa dos Patos, RS, Brasil. Nauplius, 2:53-74.

CISNEROS, K.O., SMIT, A.J., LAUDIEN, J. \& SCHOEMAN, D.S. 2011. Complex, dynamic combination of physical, chemical and nutritional variables controls spatio-temporal variation of sandy beach community structure. PloS ONE. 6(8):e23724, http:// dx.doi.org/10.1371/journal.pone.0023724

COELHO, V.R. \& RODRIGUES, S.A. 2001. Setal diversity, trophic modes and functional morphology of feeding appendages of two callianassid shrimps, Callichirus major and Sergio mirim (Decapoda: Thalassinidea: Callianassidae). J. Nat. Hist. 35:14471483, http://dx.doi.org/10.1080/002229301317067638

COLOMBINI, I. \& CHELAZZI, L. 2003. Influence of allochthonous input on sandy beach communities. Oceanogr. Mar. Biol. Ann. Rev. 41:115-159.

COLOMBINI, I., BRILli, M., FALLACI, M., GAGNARLI, E. \& CHELAZZI, L. 2011. Food webs of a sandy beach macroinvertebrate community using stable isotopes analysis. Acta Oecol. 37:422-432, http://dx.doi.org/10.1016/j.actao.2011.05.010

DEFEO, O. \& MCLACHLAN, A. 2005. Patterns, processes and regulatory mechanisms in sandy beach macrofauna: a multi-scale analysis. Mar. Ecol. Prog. Ser. 295:1-20, http://dx.doi.org/10.3354/ meps 295001

DEFEO O. \& MCLACHLAN, A. 2011. Coupling between macrofauna community structure and beach type: a deconstructive metaanalysis. Mar. Ecol. Prog. Ser. 433:29-41, http://dx.doi.org/ 10.3354/meps09206

DEFEO, O., JARAMILlO, E. \& LYONNET, A. 1992. Community structure and intertidal zonation of the macroinfauna on the Atlantic coasts of Uruguay. J. Coast. Res. 8(4):830-839.

DEFEO, O., GÓMEZ, J. \& LERCARI, D. 2001. Testing the swash exclusion hypothesis in sandy beach populations: the mole crab Emerita brasiliensis in Uruguay. Mar. Ecol. Prog. Ser. 212:159-170, http://dx.doi.org/10.3354/meps212159

DEFEO, O., LERCARI, D. \& GÓMEZ, J. 2003. The role of morphodynamics in structuring sandy beach populations and communities: what should be expected? J. Coast. Res. 35(SI):352-362.

DEFEO, O., MCLACHLAN, A., SCHOEMAN, D.S., SCHLACHER, T.A., DUGAN, J., JONES, A., LASTRA, M. \& SCAPINI, F. 2009. Threats to sandy beach ecosystems: A review. Est. Coast. Shelf Sci. 81(1):1-12, http://dx.doi.org/10.1016/ j.ecss.2008.09.022

DELGADO, M. 1989. Abundance and distribution of microphytobenthos in the bays of Ebro Delta (Spain). Est. Coast. Shelf Sci. 29(2):183-194, http://dx.doi.org/10.1016/0272-7714(89)90007-3

DIAZ, A.F., STUDZINSKI, C.D. \& MECHOSO, C.R. 1998. Relationships between precipitation anomalies in Uruguay and Southern Brazil and sea surface temperature in the Pacific and Atlantic oceans. J. Clim. 11:251-271, http://dx.doi.org/10.1175/ 1520-0442(1998)011<0251:RBPAIU > 2.0.CO;2
DU PREEZ H.H, MCLACHLAN A, MARAIS, J.F.K, \& COCKCROFT, A.C. 1990. Bioenergetics of fishes in a high-energy surf-zone. Mar. Biol. 106:1-12, http://dx.doi.org/10.1007/ BF02114669

DUGAN, J.E., HUBBARD, D.M., MCCRARY, M.D. \& PIERSON, M.O. 2003. The response of macrofauna communities and shorebirds to macrophyte wrack subsidies on exposed sandy beaches of southern California. Est. Coast. Shelf Sci. 58S:25-40, http:// dx.doi.org/10.1016/S0272-7714(03)00045-3

ESCOFET, A. 1973. Observaciones sobre alimentación y hábitos cavadores en Bathyporeiapus ruffoi y Bathyporeiapus bisetosus (Amphipoda: Oedicerotidae). Physis. 32(84):95-103.

ESTEVES, L.S., PIVEL, M.A.G., SILVA, A.R.P., BARLETTA, R.C., VRANJAC, M.P., OLIVEIRA, U.R. \& VANZ, A. 2000. Beachfront owners perception of erosion along an armored shoreline in Southern Brazil. Pesq. Geoc. 27(2):93-109.

FAUCHALD, K. \& JUMARS, P.A. 1979. The diet of worms: a study of polychaete feeding guilds. Oceanogr. Mar. Biol. Ann. Rev. 17:193-284.

FIGUEIREDO, S.A. 2013. Modelling climate change effects in southern Brazil. J. Coast. Res. 65(SI):1933-1938.

GARCIA, V.M.T. \& GIANUCA, N.M. 1997. The Beach and Surf Zone. In Subtropical Convergence Environments: The Coast and Sea in the Southwestern Atlantic (Seeliger, U., Odebrecht, C. \& Castello, J.P. eds.). Springer-Verlag, Berlin, p. 166-170.

GIANUCA, N.M. 1983. A preliminary account of the ecology of sandy beaches in Southern Brazil. In Sandy Beaches as Ecosystems (Mclachlan, A., \& Erasmus, T., eds.). Springer, Netherlands, p.413-419.

GIANUCA, N.M. 1997a. Benthic Beach Invertebrates. In Subtropical Convergence Environments: The Coast and Sea in the Southwestern Atlantic (Seeliger, U., Odebrecht, C., \& Castello, J.P. eds.). Springer-Verlag, Berlin, p.114-117.

GIANUCA, N.M. 1997b. A fauna das dunas costeiras do Rio Grande do Sul. Oecol. Bras. 3:121-133, http://dx.doi.org/10.4257/ oeco.1997.0301.08

GIRÃO, M.M.L. 2009. Variação espaço-temporal de Ocypode quadrata sob a influência de um gradiente antrópico na praia do Cassino, Rio Grande do Sul - Brasil. MSc. Dissertation in Biological Oceanography, Federal University of Rio Grande - FURG, Rio Grande, Brazil.

GRIMM, A.M., FERRAZ, S.E.T. \& GOMES, J. 1998. Precipitation anomalies in Southern Brazil associated with El Niño and La Niña events. J. Clim. 11:2863-2880, http://dx.doi.org/10.1175/15200442(1998)011<2863:PAISBA > 2.0.CO;2

HAIMOVICI, M. 1997. Demersal and Benthic Teleosts. In Subtropical Convergence Environments:The Coast and Sea in the Southwestern Atlantic (Seeliger, U., Odebrecht, C, Castello, J.P. eds.). SpringerVerlag, Berlin, p.129-136.

HEYMANS, J.J. \& MCLACHLAN, A. 1996. Carbon budget and network analysis of a high-energy beach/surf-zone ecosystem. Est. Coast. Shelf Sci. 43:485-505, http://dx.doi.org/10.1006/ecss.1996.0083

JARAMillo, E., MCLACHLAN, A., COETEZEE, P. 1993. Intertidal zonation patterns of macroinfauna over a range of exposed sandy beaches in south-central Chile. Mar. Ecol. Prog. Ser. 101:105-117, http://dx.doi.org/10.3354/meps101105

KEMP, P.F. 1986. Direct uptake of detrital carbon by the deposit-feeding polychaete Euzonus mucronata (Treadwell). J. Exp. Mar. Biol. Ecol. 99:49-61, http://dx.doi.org/10.1016/0022-0981(86)90020-1

KRUSCHE, N., SARAIVA, J.M.B. \& REBOITA, M.S. 2003. Normais Climatológicas Provisórias de 1991 a 2000 para Rio Grande, RS. Editora FURG, Rio Grande.

LASIAK, T.A. 1981. Nursery grounds of juvenile teleosts:evidence from the surf zone of King's Beach, Port Elizabeth. S. Afr. J. Sci. 77:388-390.

LASIAK, T. \& MCLACHLAN, A. 1987. Opportunistic utilization of mysid shoals by surf-zone teleosts. Mar. Ecol. Prog. Ser. 37:1-7, http://dx.doi.org/10.3354/meps037001 
LEBER, K.M. 1982. Seasonality of macroinvertebrates on a temperate, high wave energy sandy beach. Bull. Mar. Sci. 32(1):86-98.

LERCARI, D., BERGAMINO, L. \& DEFEO, O. 2010. Trophic models in sandy beaches with contrasting morphodynamics:comparing ecosystem structure and biomass flow. Ecol. Model. 221:2751-2759, http://dx.doi.org/10.1016/j.ecolmodel.2010.08.027

LIMA, M.S.P. \& VIEIRA, J.P. 2009. Variação espaço-temporal da ictiofauna da zona de arrebentação da Praia do Cassino, Rio Grande do Sul, Brasil. Zoologia. 26(3):499-510, http://dx.doi.org/ 10.1590/S1984-46702009000300014

MASSELINK, G. \& SHORT, A.D. 1993. The effect of tide range on beach morphodynamics and morphology:a conceptual beach model. J. Coast. Res. 9:785-800.

MCLACHLAN, A. 1980. Exposed sandy beaches as semi-closed ecosystems. Mar. Environ. Res. 4:59-63, http://dx.doi.org/ 10.1016/0141-1136(80)90059-8

MCLACHLAN, A. \& BROWN, A.C. 2006. The Ecology of Sandy Shores. Academic Press, New York.

MCLACHLAN, A. \& DORVLO, A. 2005. Global patterns in sandy beach macrobenthic communities. J. Coast. Res. 21(4):674-687, http://dx.doi.org/10.2112/03-0114.1

MCLACHLAN, A., ERASMUS, T., DYE, A.H., WOOLDRIDGE, T., VAN DER HORST, G., ROSSOUW, G., LASIAK, T.A. \& MCGWYNNE, L. 1981. Sand beach energetics:an ecosystem approach towards a high energy interface. Est. Coast. Shelf Sci. 13:11-25, http://dx.doi.org/10.1016/S0302-3524(81)80102-8

MCLACHLAN, A., JARAMILLO, E., DONN, T.E. \& WESSELS, F, 1993. Sand beach macrofauna communities and their control by the physical environment:a geographical comparison. J. Coast. Res. 15(SI):27-38.

MCLACHLAN, A., JARAMILLO, E., DEFEO, O., DUGAN, J., DE RUYCK A \& COETZEE, P. 1995. Adaptations of bivalves to different beach types. J. Exp. Mar. Biol. Ecol. 187:147-160, http:// dx.doi.org/10.1016/0022-0981(94)00176-E

MCLACHLAN, A., WOOLDRIDGE, T. \& DYE, A.H. 1981. The ecology of sandy beaches in southern Africa. S. Afric. J. Zool. 16:219-231.

MINASI, D.M. 2013. Composição e variabilidade espaço-temporal da macrofauna bentônica da Praia dos Concheiros, extremo sul do Brasil. Monograph in Oceanography, Federal University of Rio Grande - FURG, Rio Grande, Brazil.

MONTEIRO-NETO, C. \& CUNHA, L.P.R. 1990. Seasonal and ontogenetic variation in food habits of juvenile Trachinothus marginatus Cuvier, 1832 (Teleostei, Carangidae) in the surf zone of Cassino Beach, RS, Brazil. Atlântica. 12(1):45-54.

MONTEIRO-NETO, C., CUNHA, L.P.R. \& MUSICK, J.A. 2003. Community structure of surf-zone fishes at Cassino Beach, Rio Grande do Sul, Brazil. J. Coast. Res. 35(SI):492-501.

NARCHI, W. 1981. Aspects of the adaptive morphology of Mesodesma mactroides (Bivalvia:Mesodesmatidae). Malacologia. 21(1-2):95-110.

NEVES, L.P., SILVA, P.S.R. \& BEMVENUTI, C.E. 2007. Zonation of benthic macrofauna on Cassino Beach, Southernmost Brazil. Braz. J. Oceanogr. 55(4):293-307, http://dx.doi.org/10.1590/S167987592007000400006

NEVES, L.P., SILVA, P.S.R. \& BEMVENUTI, C.E. 2008. Temporal variability of benthic macrofauna on Cassino Beach, Southernmost Brazil. Iheringia (Zoo). 98:36-44, http://dx.doi.org/10.1590/S007347212008000100005

ODEBRECHT, C., SEGATTO, A.Z. \& FREITAS, C.A. 1995. Surfzone chlorophyll $a$ variability at Cassino Beach, Southern Brazil. Est. Coast. Shelf Sci. 41:81-90, http://dx.doi.org/10.1006/ ecss. 1995.0054

ODEBRECHT, C., BERGESCH, M., RÖRIG, L.R. \& ABREU, P.C. 2010. Phytoplankton interannual variability at Cassino Beach, southern Brazil (1992-2007) with emphasis on the surf zone diatom Asterionellopsis glacialis. Est. Coast. 33:570-583, http://dx.doi.org/ $10.1007 / \mathrm{s} 12237-009-9176-6$
ODEBRECHT, C., DU PREEZ D.R, ABREU, P.C \& CAMPBELL, E.E. 2013. Surf zone diatoms:a review of the drivers, patterns and role in sandy beaches food chains. Est. Coast. Shelf Sci. http://dx. doi.org/10.1016/j.ecss.2013.07.011.

ORENSANZ, J.M., SCHWINDT, E., PASTORINO, G., BORTOLUS, A., CASAS, G., DARRIGRAN, G., ELÍAS, R., GAPPA, J.J.L., OBENAT, S., PASCUAL, M., PENCHASZADEH, P., PIRIZ, M.L., SCARABINO, F., SPIVAK, E.D. \& VALLARINO, E.A. 2002. No longer the pristine confines of the world ocean:a survey of exotic marine species in the southwestern Atlantic. Biol. Invasions. 4:115-143, http:// dx.doi.org/10.1023/A:1020596916153

PARDO, E.V. \& AMARAL, A.C.Z. 2004. Feeding behavior of Scolelepis sp. (Polychaeta:Spionidae). Braz. J. Oceanogr. 52(1):75-79, http://dx.doi.org/10.1590/S1679-87592004000100007

PARISE, C.K., CALLIARI, L.J. \& KRUSCHE, N. 2009. Extreme storm surges in the south of Brazil:atmospheric conditions and shore erosion. Braz. J. Oceanogr. 57(3):175-188, http://dx.doi.org/ 10.1590/S1679-87592009000300002

PENCHASZADEH, P.E. 2004. Caracoles, Almejas y Mejillones. In La Vida entre Mareas:Vegetales y Animales de las Costas de Mar del Plata, Argentina (Boschi , E.E. \& Cousseau M.B. eds.). INIDEP, Mar del Plata, p. 253-270.

PEREIRA, P.S., CALliARI, L.J. \& BARLETTA, R.C. 2010. Heterogeneity and homogeneity of Southern Brazilian beaches:A morphodynamic and statistical approach. Cont. Shelf Res. 30:270 280, http://dx.doi.org/10.1016/j.csr.2009.11.007

PEZZUTO, P.R. 1998. Population dynamics of Sergio mirim (Rodrigues, 1971) (Decapoda:Thalassinidea:Callianassidae) in Cassino Beach, southern Brazil. Mar. Ecol. 19(2):89-109, http:// dx.doi.org/10.1111/j.1439-0485.1998.tb00456.x

PINHEIRO, C. 2013. Embancamentos da macrofauna bentônica e sua relação com eventos meteorológicos em uma praia arenosa do extremo sul do Brasil. Monograph in Oceanography, Federal University of Rio Grande - FURG, Rio Grande, Brazil.

QUEIROZ, L.R. 2008. Variação espaço-temporal da biomassa macrofaunal bentônica da zona de varrido da praia do Cassino - RS, Brasil. MSc. Dissertation in Biological Oceanography, Federal University of Rio Grande - FURG, Rio Grande, Brazil.

RAO, V.B. \& HADA, K. 1990. Characteristics of rainfall over Brazil:annual variations and connections with the Southern Oscillation. Theor. Appl. Clim. 42:81-91, http://dx.doi.org/ 10.1007/BF00868215

RIOS, E.C. 2009. Compendium of Brazilian Sea Shells. Evangraf, Rio Grande.

ROBERTS, C.M. \& HAWKINS, J.P. 1999. Extinction risk in the sea. Trends Ecol. Evolut. 14(6):241-246, http://dx.doi.org/10.1016/ S0169-5347(98)01584-5

ROBERTSON, J.R. \& PFEIFFER, W.J. 1982. Deposit-feeding by the ghost crab Ocypode quadrata (Fabricius). J. Exp. Mar. Biol. Ecol. 56:165-177, http://dx.doi.org/10.1016/0022-0981(81)90187-8

RODRIGUES, F.L. \& VIEIRA, J.P. 2010. Feeding strategy of Menticirrhus americanus and Menticirrhus littoralis (Perciformes:Sciaenidae) juveniles in a sandy beach surf zone of southern Brazil. Zoologia. 27(6):873-880, http://dx.doi.org/10.1590/ S1984-46702010000600006

RÖRIG, L.R. \& GARCIA, V.M.T. 2003. Accumulations of the surfzone diatom Asterionellopsis glacialis (Castracane) Round in Cassino Beach, Southern Brazil, and its relationship with environmental factors. J. Coast. Res. 35(SI):167-177.

SANTOS, P.J.P. 1991. Morphodynamical influence of a temporary freshwater stream on the population dynamics of Scolelepis gaucha (Polychaeta:Spionidae) on a sandy beach in Southern Brazil. Bull. Mar. Sci. 48(3):657-664.

SANTOS, P.J.P. 1994. Population dynamics and production of Scolelepis gaucha (Polychaeta:Spionidae) on the sandy beaches of Southern Brazil. Mar. Ecol. Prog. Ser. 110:159-165, http:// dx.doi.org/10.3354/meps110159 
SHORT, A.D. 1996. The role of wave height, period, slope, tide range and embaymentisation in beach classifications:a review. Rev. Chil. Hist. Nat. 69:589-604.

SOARES, A.G., SCHLACHER, T.A. \& MCLACHLAN, A. 1997. Carbon and nitrogen exchange between sandy beach clams (Donax serra) and kelp beds in the Benguela coastal upwelling region. Mar. Biol. 127:657-664, http://dx.doi.org/10.1007/s002270050056

SPEYBROECK, J., ALSTEENS, L., VINCX, M. \& DEGRAER, S. 2007. Understanding the life of a sandy beach polychaete of functional importance - Scolelepis squamata (Polychaeta:Spionidae) on Belgian sandy beaches (northeastern Atlantic, North Sea). Est. Coast. Shelf Sci. 74:109-118, http://dx.doi.org/10.1016/ j.ecss.2007.04.002

TABAJARA, L.L., MARTINS, L.R. \& ALMEIDA, L.E.S.B. 2004. Respostas e recomposição das praias e dunas após sequência de ciclones extratropicais. Gravel. 2:104-121.

TOMAZELLI, L.J. \& VILLWOCK, J.A. 1992. Considerações sobre o ambiente praial e a deriva litorânea de sedimentos ao longo do litoral norte do Rio Grande do Sul, Brasil. Pesq. Geoc. 19(1):3-12.

TROTT, T.J. 1999. Gustatory responses of ghost crab Ocypode quadrata to seawater extracts and chemical fractions of natural stimuli. J. Chem. Ecol. 25(2):375-388, http://dx.doi.org/10.1023/ A:1020859115984
VIANA, M.G. 2008. Avaliação de efeitos antrópicos sobre a distribuição do poliqueta Euzonus furciferus (Eulhers, 1897) na Praia do Cassino RS, Brasil. MSc. Dissertation in Biological Oceanography, Federal University of Rio Grande - FURG, Rio Grande, Brazil.

VIEIRA, J.P. 1991. Juvenile mullets (Pisces:Mugilidae) in the Estuary of Lagoa dos Patos, RS, Brazil. Copeia. 2:409-418, http:// dx.doi.org/10.2307/1446590

VOOREN, C.M. 1997. Sea and Shore Birds. In Subtropical Convergence Environments:The Coast and Sea in the Southwestern Atlantic (Seeliger, U., Odebrecht, C. \& Castello, J.P.., eds.). Springer-Verlag, Berlin, p. 154-159.

VOOREN, C.M. \& CHIARADIA, A. 1990. Seasonal abundance and behavior of coastal birds on Cassino beach, Brazil. Ornit. Neotrop. 1:9-24.

WARNER, G.F. 1977. The Biology of Crabs. Elek Science, London.

WOLCOTT, T.G. 1978. Ecological role of ghost crabs Ocypode quadrata (Fabricius) on an ocean beach:scavengers or predators? J. Exp. Mar. Biol. Ecol. 31(1):67-82, http://dx.doi.org/10.1016/ 0022-0981(78)90137-5

YANNICELLI, B., PALACIOS, R. \& GIMÉNEZ, L. 2002. Swimming ability and burrowing time of two cirolanid isopods from different levels of exposed sandy beaches. J. Exp. Mar. Biol. Ecol. 273:73-88, http://dx.doi.org/10.1016/S0022-0981(02)00146-6 